\section{Henri Lefebvre on education: Critique and pedagogy}

\section{Sue Middleton}

Faculty of Education, University of Waikato, New Zealand
Policy Futures in Education $0(0) 1-17$

(C) Author(s) 2016

Reprints and permissions: sagepub.co.uk/journalsPermissions.nav DOI: 10.1177/147821031667600। pfe.sagepub.com

(SAGE

\begin{abstract}
The 'spatial turn' in education policy studies fuelled interest in Lefebvre's work: initially, in his work Production of Space and, more recently, Rhythmanalysis and Right to the City. Yet, although in these texts Lefebvre critiques universities and schools and introduces original pedagogical concepts, their educational strands have attracted little attention. Lefebvre's other works available in English have been largely overlooked in education literature. As France's first Professor of Sociology, Lefebvre was passionately engaged with education: in particular, teaching, competing for government grants and leading student activism. Critiques of education are threaded through Lefebvre's three-volume Critique of Everyday Life, his writings on architecture and anthologies. Lefebvre's work, The Explosion, is surprisingly neglected. A critique of French universities, it analyses student protests across Paris in 1968 - events in which Lefebvre was a leading activist. In geography and philosophy there are burgeoning secondary literatures on Lefebvre. Laying groundwork for such a literature in education, I survey Lefebvre's references to education in all the works available in English. Arguing that Lefebvre was an educational thinker in his own right, this paper sketches a 'roadmap' for educational readings of Lefebvre's prolific and largely sociological writing. This paper falls into three parts. The first uncovers core Marxist and phenomenological foundations of Lefebvre's critiques of universities and schools. Building on these, it introduces Lefebvre's pedagogical concepts. The second part contextualises these in relation to 'New' (or 'Progressive') education movements at 'critical moments' of 20th-century history. It includes a case study of one such moment - the 1968 Parisian student uprising - then outlines Lefebvre's summation of education in the late 20th century. The third part draws together four 'Lefebvrian' pedagogical principles and considers their relevance today. Educational readings of Lefebvre, I suggest, can help educationists identify 'cracks or interstices' in 'technocratic rationality', suggesting strategies for resisting contemporary neo-liberal regimes.
\end{abstract}

\title{
Keywords
}

Henri Lefebvre, critique of everyday life, pedagogy, space

\section{Corresponding author:}

Sue Middleton, Wilf Malcolm Institute for Educational Research, University of Waikato, Te Whare Wananga o Waikato, Gate I Knighton Road, Private Bag 3105, Hamilton 3240, New Zealand

Email: s.middleton@waikato.ac.nz 
Now and again we will need to lay bare a certain nefarious pedagogic illusion, and in doing so we will be able to highlight the part played by education and its importance in everyday life. This illusion is twofold: on the one hand, a fetishism of the partial, and thus of the fragmentary and the specialised, an acceptance of fragmentation and the dismissal of totality; on the other hand, a fetishism of the total, an equalising of differences, a superficial encyclopedism, and a belief in the complete mastery of pedagogy and human knowledge over human nature. There is a middle way between the dismissal of totality and the fetishism of the total, and critique of everyday life can help to define it. (Lefebvre, 2002: 68)

The 'spatial turn' in education policy studies fuelled interest in Lefebvre's work: initially, in Production of Space (1991c) (Gulson and Symes, 2007; Middleton, 2010). More recently, educationists have cited Lefebvre's Rhythmanalysis (2004; Mathieson, 2015; Middleton, 2010, 2012) and Right to the City (1996; Ford, 2013). Yet, although in these texts Lefebvre critiques universities and schools and introduces original pedagogical concepts, their educational strands have attracted little attention.

Lefebvre's other works available in English have been largely overlooked in education literature. As France's first Professor of Sociology, Lefebvre (1901-1991) was passionately engaged with education: in particular, teaching, competing for government grants and leading student activism. Critiques of French education are threaded through Lefebvre's three-volume Critique of Everyday Life (1991a, 2002, 2005), his writings on architecture (2014), anthologies of his essays and extracts from longer works, most notably his four untranslated volumes on the state (Brenner and Elden, 2009b; Elden et al., 2003). Lefebvre's book, The Explosion (1969), is surprisingly neglected. A critique of French universities, it analyses the eruption of student protests across Paris in 1968 - events in which Lefebvre was such a leading figure that he is described as 'the father of that movement' (Harvey, 1991: 430).

In geography, philosophy and other disciplines, there are burgeoning secondary literatures on Lefebvre (including Elden, 2004; Shields, 1999). Laying groundwork for such a literature in education, my recent monograph surveyed Lefebvre's references to education in all the works available in English and put them to work in research. Lefebvre, I concluded, should be regarded as an educational thinker in his own right (Middleton, 2014). Developing this argument further, this paper sketches a 'roadmap' for educational readings of Lefebvre's prolific, often densely sociological, writing.

Spanning the 1930s-1980s, Lefebvre wrote around 70 books (Elden, 2004), only 10 of which have been translated. Generalising from so small a sample raises questions of validity. Furthermore, English translations usually appeared decades after publication in French, so the topics, contexts and trajectories of Lefebvre's thought appear in a different 'temporal sequencing and spacing' (Kofman and Lebas, 1996b: 4). However, my reading of the translated works as representative of Lefebvre's educational thinking is supported by his English-language interlocutors (Elden, 2004; Shields, 1999). Kipfer, for example, designates Lefebvre's lifetime's oeuvre as a 'conceptual constellation' in which it is 'not possible to identify an "epistemological break", (2009: xxv).

This paper falls into three parts. The first uncovers core Marxist and phenomenological foundations of Lefebvre's critiques of universities and schools. Building on these, it introduces Lefebvre's pedagogical concepts. The second part contextualises these in relation to 'New' (or 'Progressive') education movements at 'critical moments' of 20thcentury history. It includes a case study of one such moment - the 1968 Parisian student uprising - then outlines Lefebvre's summation of education in the late 20th century. The third part draws together four 'Lefebvrian' pedagogical principles and considers their 
relevance today. Educational readings of Lefebvre, I suggest, can help educationists identify 'cracks or interstices' in 'technocratic rationality', suggesting strategies for resisting contemporary neo-liberal regimes.

\section{Lefebvre's educational critique: Marxist and Heideggerian foundations}

During the 1930s, Lefebvre translated Marx's 1844 Manuscripts and works by Heidegger into French. These laid foundations for Lefebvre's writing (Elden, 2006), including his educational thought. Employed as a sociologist, but critical of disciplinary fragmentations, Lefebvre worked 'on the borders of philosophy and the social sciences' (2005: 165), although admitting to a 'tendency to privilege sociology' (2005: 18). Marx, he concluded, was 'not a sociologist', but there was 'a sociology in Marx' (1968: 22). Marxist sociology's object of inquiry was 'the process of historical becoming' (2002: 129). Lefebvre elaborates: 'active man creates the human world, and through the act of production, produces himself. He does not simply produce things, implements or goods; he also produces history and situations. He creates "human nature" (2002: 95).

To research 'the production of human nature', Lefebvre devised his dialectical method, 'critique of everyday life', strongly influenced by Heidegger's phenomenological focus on being-in-the-world. Working 'between' Marx and Heidegger (Elden, 2006), oscillating between macro-, meso- and micro-levels of inquiry, Lefebvre connected 'the simple moments and the highest moments of life' (Lefebvre, 1991a: 86). His objective, I argue, was in essence pedagogical:

To study the everyday is to wish to change it. To change the everyday is to bring its confusions into the light of day and into language; it is to make its latent conflicts apparent, and thus to burst them asunder. It is therefore both theory and practice, critique and action. (Lefebvre, 2002: 209)

In 1948, launching Volume 1 of Critique of Everyday Life (henceforth Critique), Lefebvre described it as 'built entirely round Marx's concept of alienation' (Lefebvre, 1991b: 3). This section addresses alienation (Marx), the everyday (Heidegger), appropriation (Marx) and dwelling (Heidegger) as conceptual foundations of Lefebvre's educational critiques and pedagogical strategies.

\section{Alienation in education's 'everyday'}

Lefebvre wrote, "man" is alienated, torn from his self and changed into a thing, along with his freedom' (1991b: 3). Marx's emphasis had been on economic alienation: 'Money, currency, commodities, capital, are nothing more than relations between human beings' (Lefebvre, 1991a: 178). Regarding Marx's work as unfinished, Lefebvre identified 'many alienations' (2002: 207). Technological (discussed later) and philosophical alienations were characteristics of the 'human nature' pedagogically (re)produced in universities and schools.

In educational institutions philosophical and economic alienation were closely linked: "knowledge accumulates and becomes "capitalised" in the same manner as the material wealth represented by objects or money' (Lefebvre, 1969: 146). An 'ideology of hierarchisation' was (re)produced (1969: 155). Valorising 'the teacher above the taught' and 'knowledge above an ignorance in search of learning and in the process of acquiring it', education was reduced to 'initiation and esotericism, and fragmented 
specialisation deprived of totality' (1969: 155). Philosophy, for example, required 'a journey into the purely abstract and conceptual ... constructed above the everyday' (Lefebvre, 2002: 56). Critique of education's everyday would uncover relations between the 'high theory' of curricula and 'trivial' interactions between students and/or professors in 'the philosophy lecture, the lycée, the town, the university' (Lefebvre, 2002: 56).

Academic knowledge was 'marked by the ruling class': it was 'the property of this class. It is administered - i.e. institutionalised - by this class' (Lefebvre, 1969: 148). Students from 'other' (marginalised) backgrounds were often alienated from what 'counts' as knowledge; even infants experiencing 'opposition between school life and family life' (Lefebvre, 2002: 50). Inequalities were thereby (re)produced:

\footnotetext{
Alienation is not a theory, an idea or an abstraction - it is rather that the theories, the ideas or the 'pure' abstractions which induce man to obliterate his living existence in favour of absolute truth, or to define himself by a theory or reduce himself to abstractions, are part of human alienation. (Lefebvre, 1991a: 167)
}

How is alienated human nature 'pedagogically produced'? How can we 'pedagogically produce' ourselves otherwise - a 'de-alienated' or liberated subjectivity?

Pedagogy is the unifying concept around which fragmented disciplines and fields comprising 'education studies' cohere. It is Lefebvre's interest in pedagogy that marks him as an educational thinker. He distinguished 'dressage, education and learning' (2004: 38-45). Military in character, dressage is 'training' or 'drill', based on routine, repetition and obedience (Lefebvre, 2004: 39; see also Foucault, 1977). A modicum of dressage is required for socialisation: 'The child, like the young animal, has its biological rhythms, which become basic but alter themselves (are altered): hunger, sleep, excretions' (Lefebvre, 2004: 43, emphasis in the original). In contrast, education opens out possibilities, engaging students in 'real' problems of 'lived' experience:

Education must not be based on the concepts of certitude or incertitude. Certitude results in dogmatism; its tendency is to move from the relative to the absolute, from partiality to totality... Education ought to centre on concrete problems that are both practical and theoretical, both empirical and conceptual. (Lefebvre, 1969: 157)

Education identifies contradictions in everyday experience: 'Contradictions give rise to problems, and thus to a set of possibilities' (2002: 209). Critique of everyday life (a critical pedagogy) aims to 'render ambiguities bearable, and to metamorphose what seems to be most unchangeable in mankind' (Lefebvre, 2002: 226). Effected by both dressage and education, learning mediates. A pedagogy is any practice, process or experience that effects learning.

In Production of Space (henceforth Production), Lefebvre's brief reference to a pedagogy of appropriation highlights pedagogy's spatial dimension. In this, Lefebvre's readings of Marx, Heidegger and other phenomenologists coalesce - Marx's concept of 'appropriation' and 'pedagogy' as critique of everyday life.

\section{Pedagogies of appropriation}

In Production, Lefebvre wrote:

It is possible to envision a sort of 'rhythm analysis' which could address itself to the concrete analysis of rhythms, and perhaps even to their use (or appropriation). Such an approach would 
seek to discover those rhythms whose existence is signalled only through mediations, through indirect effects or manifestations. Rhythm analysis might eventually even displace psychoanalysis, as being more concrete, more effective, and closer to a pedagogy of appropriation (the appropriation of the body, as of spatial practice). (1991c: 205)

Decoding this requires Lefebvre's spatial-rhythmanalytical, architectural and linguistic vocabularies. I address each in turn.

Rhythms of place. In Lefebvre's work, the 'concept of space denotes and connotes all possible spaces, whether abstract or real, mental or social' (Lefebvre, 1991c: 299). Rhythm is energy: 'Energy animates, renders time and space conflictual' (Lefebvre, 2004: 60). The polyrhythms of everyday life mediate 'between nature and culture' (2002: 357).

Production explored 'the dialectical relationship which exists within the triad of the perceived, the conceived and the lived' (Lefebvre, 1991c: 39). The perceived is social space - the common sense, taken-for-granted physical/embodied world of 'social practice, the body, the use of the hands, the practical basis of the perception of the outside world' (1991c: 38). A school is an assemblage of buildings, trees, paths, climbing frames and gardens. Schoolchildren's 'habitual' spatial practices include walking well-trodden paths to school, switching on computers and sitting at desks. Rhythms of perceived spaces include those of the body and of nature: 'heartbeats, breathing, being awake and being asleep by turns, being hungry, being thirsty, and so on' (Lefebvre, 2005: 129). Schooling may be rhythmed by tides, seasons, storms and droughts.

Conceived spaces are abstract, mental (and legal/bureaucratic) enclosures: the 'lots' of 'owned' commercial, state or private property or the administrative divisions of school 'classes' or departments. Conceived spaces are 'discursively constructed by professionals and technocrats' (Simonsen, 2005: 7). They emanate from 'the "world" of commodities, its "logical" and its worldwide strategies; as well as the power of money and that of the political state' (Lefebvre, 1991c: 53). 'Representations of space' are codified visualisations of the conceived: architectural blueprints, timetables.

Critique of education's everyday traces 'social relations' connecting the 'near order' (home, campus, department) with the 'far order' of political, administrative, commercial or spiritual authorities. It is 'everyday life which measures and embodies the changes which take place "somewhere else", in the "higher realms"" (Lefebvre, 2002: 45). Institutions 'mediate' policies emanating from the metropolitan 'far order': 'Political power knows how to utilise and manipulate time, dates, timetables. It combines the unfurlings [déploiements] of those that it employs (individuals, groups, entire societies), and rhythms them' (Lefebvre, 2004: 68). Through enclosures of time and space, educational bureaucracies 'train' - or, in Foucault's (1977) terms, 'discipline' - bodies (dressage). These rhythms of the conceived are linear, regular, measurable. They interpenetrate with pulsing cycles of nature and the body: 'From the very beginning of industrial organisation, there is a sudden mutual interference between rhythmical vital processes and linear operations' (Lefebvre, 2005: 129).

A space/place is at once conceived, perceived and lived. We 'live' spaces by attributing meaning to them: emotional, spiritual, historical, cultural or genealogical. A school may be located on lands with spiritual significance to indigenous peoples (Middleton and McKinley, 2010); a child's family/tribal dramas played out in its grounds. Increasingly dominated or 'colonised' by the abstract 'mental spaces' of the conceived, the 'lived' taps into unconscious, imaginary and symbolic dimensions of experience. It erupts to the surface through the 
representational spaces of poetry, painting, theatre, symbol, myth and festival. Seeking '... a revived unity and totality - of the experiential, the philosophical and the political' (2005: 17), Lefebvre argued that if there was also 'a magical dimension to daily life..., that was also its complexity and its richness' (2005: 17).

Rhythms of lived spaces are of varying intensity and amplitude. They include 'explosive and endogenous' (Lefebvre, 1991c: 204) eruptions from the cultural unconscious (as in carnivals or riots). Cycles of cultural rituals keep pace with and accord poetic or religious meaning to cycles of nature. There is eurhythmia when seasonal and cultural cycles 'unite with one another in a state of health, in normal... everydayness' (Lefebvre, 2004: 16). But arrhythmia is experienced when natural and cultural cycles no longer synchronise: emigration across hemispheres transplants the northern winter festival of Christmas into a southern summer (Middleton, 2010). When rhythms 'are discordant, there is suffering, a pathological state' (Lefebvre, 2004: 16). In educational institutions, imperatives of the conceived - deadlines, appraisals, standards - 'colonise' cyclic pulses of the lived (pregnancy, sickness, childrearing, tribal obligations). The physical, psychological/ intellectual or emotional growth of a child may be 'arrhythmic' with linear (conceived) institutional 'levels', 'stages' or 'standards.'

Conceived spaces are dominated spaces: 'Domination of physical nature, the result of technological processes, ravages nature while allowing societies to substitute its products for nature itself' (Lefebvre, 2003c: 130). As 'products', mass-produced 'buildings' are 'constructed according to technological dictates, inhabited by users in homogenous, shattered space' (Lefebvre, 1991c: 165). Their 'abstract and functional character' had been 'brought to its present form by a state bureaucracy' (Lefebvre, 1996: 79). With its 'roots in warehouses, barracks, depots and rental housing' (1991c: 222-223), this style had been characteristic of 'administrative buildings from the nineteenth century on, in schools, railway stations, town halls, police stations or ministries' (1991c: 227). We might think of dressage as a 'pedagogy of domination'.

In contrast, 'Appropriation does not ravage nature, but transforms it - the body and biological life provided, and the time and space - into human property' (2003c: 130). By 'property' here Lefebvre, following Marx, means 'use' (not exchange) value. Over time, each society 'appropriates, that is to say, adapts to its own ends, pre-existing space, whose patterns had been previously formed. Slow changes, penetrating a space that had already been consolidated' (Lefebvre, 2003b: 212). A 'pedagogy of appropriation' involves student appropriation of educational spaces. As architectural spaces, schools and universities configure (and are configured by) theory, language, imagination and feeling. And here Lefebvre turns to Heidegger's notion of dwelling.

A place for the child to dwell? Lefebvre described architecture as a 'mode of imagination. The starting point for this redefinition was the concept of habitation, understood as the half-real, half-imaginary distribution of times and places of everyday life' (Stanek, 2014: xiii-xiv). Lefebvre elaborates: 'habiter or way of living is a quality of the person, it is not an accident and links in with actions of building, thought and speech' (2003c: 121). While the 'building' is a conceived space, a dwelling place is 'lived':

Dwelling, in its essence, is poetic... 'It could be', says Heidegger, 'that our dwellings that lack poetry, our inability to take the measure of man and his heart, spring from a strange kind of excess: a rage for measurement and calculation'. (Lefebvre, 2003c: 122) 
While 'buildings' or 'habitats' are produced by, and (re)produce, 'a rage for measurement and calculation', 'dwelling' encourages creativity. Here, Lefebvre's poetic language is worth quoting at length:

Dwelling, a social and yet poetic act, generating poetry and art work, fades in the face of housing, an economic function. The 'home', so clearly evoked and celebrated by Gaston Bachelard, likewise vanishes: the magic place of childhood, the home as womb and shell, with its loft and its cellar full of dreams. Confronted with functional housing, constructed according to technological dictates, inhabited by users in homogenous, shattered space, it sinks and fades into the past. (Lefebvre, 2005: 94; see also Bachelard, 2002)

In the contradictory spaces of schooling, learning is a mediation of the dressage of habitat (dominated, conceived) and the educational practices of dwelling (in lived, appropriated spaces). Lefebvre's pedagogical question is "How to create a "habitation" that will give form without impoverishing, a shell that will allow the young to grow without being prematurely closed up? How is this ambiguous "human being"...to be offered a “dwelling place'?' (2003a: 138). Classrooms that are 'dwelling places' for children are consonant with other 'magic places of childhood', with 'lofts and cellars full of dreams' (Lefebvre, 2005: 94). Appropriated for children's 'own use' such classrooms are infused with their personal, cultural, spiritual and emotional meanings (Middleton, 2012; 2014: 83-110). To study such 'meanings', drawing on linguistics, Lefebvre devised his own semiotic vocabulary (2002: 276-314). Lefebvre's semiotic field is important to his educational critique and his pedagogy.

The semiotic field. Lefebvre saw Marx's dialectical method as uncovering 'the genesis of "representations" and feelings; it reveals their conditions, their practical functions, the way they work... It can make links between each "representation", each symbol, each myth, each concept, and a specific human era' (1991a: 194; see also 2009b). His semiotic lexicon included the signal, the sign, the symbol and the image (Lefebvre, 2002: 276-314; 1991c: 130-141).

Signals are commands within codified systems. They emanate from the 'conceived' realms of modernity - industry, technology and bureaucracy: 'stop/go, on-off', demanding a conditioned response. The school bell is an example. The sign is epitomised by the word. In families and schools, an overload of 'signs' can alienate: mind splits from body, reason from emotion, 'public' from 'private' identity:

Between self and self, between the body and its Ego - or, better, between the Ego-seeking-toconstitute itself and its body. The context here is necessarily that of a long-term learning process, the process of formation and deformation which the immature and premature human child must undergo on the way to familial and social maturity. But what is it exactly that slips into the interstice in question? The answer is: language, signs, abstraction - all necessary yet fateful, indispensable yet dangerous. This is a lethal zone thickly strewn with dusty, mouldering words. What slips into it is what allows meaning to escape the embrace of lived experience, to detach itself from the fleshly body. (Lefebvre, 1991c: 203)

When linguists 'separate the language chain from its environment' (Lefebvre, 2002: 280), they are 'left with an abstraction: language as a verbal system', a sign. Describing reading as 'a practical experience which children learn at an early stage', Lefebvre warned of alienation when 'graded readers' reduce language to abstract systems of signs, devoid of 
experiential meaning. The hegemony of the visual (reading) and the sign (the word) can alienate students from their other senses. Lefebvre contrasted reductionist academia with the polytechnic, which 'assumes a practical orientation', cultivating other senses (Lefebvre, 2014: 39). Taste, as in the training of chefs, could become 'as discriminating as sight or hearing and could comprehend objects as complex as those found in painting or music' (2014: 39).

To encompass the 'lived', Lefebvre adds the symbol and the image. The symbol (a uniform for example) 'includes and excludes, by bringing the members of one particular group closer together, while excluding other individuals and groups' (2002: 284). Resonating deep in the unconscious, some symbols bring to the surface ancient archetypes, dreams and visions of a culture: 'Symbols come in groups. We will say that they constitute configurations or constellations: cosmic symbolisms, tragic symbolisms, religious symbolisms, etc.' (Lefebvre, 2002: 286). In the symbols of everyday life, 'the modern and the residual can co-exist' (Moran, 2010: 56). Astrological star signs, the rune and the pentangle are residues of 'the mysterious, the sacred and the diabolical, magic, ritual, the mystical' suppressed by the rationalism of Modernity (Lefebvre, 1991a: 17). 'Modernity' was merely 'a crust over the tunnels and caves of uncertainty and illusion' (Lefebvre, 1971: 109). Lefebvre explains, 'everything that once represented an affective, immediate and primitive relationship between man and the world - everything that was serious, deep, cosmic - is displaced and sooner or later gradually enters the domain of play, or art' (1991a: 17). Residues of the mysterious and the magical survived as degraded caricatures: in 'irrational' realms relegated to the 'feminine' in popular magazines (Lefebvre, 2002: 82-87), in children's stories (the 'wicked witch'), games and toys (1991a: 118). (In contrast, Lefebvre described modern industrial 'sign-toys: miniature rifles, a ladder' (2014: 34).)

While the symbol bears collective (cultural) meaning, the image 'is an individual work, but it is communicable. Unlike the sign, it does not belong in abstractness, any more than it does in sensuousness' (Lefebvre, 2002: 287). The image is 'an aspect of expressivity. Communicative and communicating, it is original and unique; it carries the hallmark of inventiveness, of spontaneous or cultivated poetry' (2002: 287).

Alienation results when the signage of the 'conceived' curriculum produces: 'a split between the objectifying and the subjectifying processes in the individual, so that the unity between them is destroyed' (Lefebvre, 1968: 10). The domination of words and signs

sets up a strange interplay between (verbal) disembodiment and (empirical) re-embodiment, between uprooting and reimplantation, between spatialisations in an abstract expanse and localisation in a determinate expanse. This is the 'mixed space' - still natural yet already produced - of the first year of life, and, later, of poetry and art. (Lefebvre, 1991c: 203)

In schooling's contradictory spaces 'expressivity is a thing of flesh and blood; mobile, unexpected, it is forever breaking through the barriers of signification, informing, communicating by means of acquired significations' (Lefebvre, 2002: 293).

At certain historical conjunctures (for example, around 1910 and, again, in 1968), expressivity erupted through the crusts of signification on a mass scale. Lefebvre termed these 'Moments'. These Moments, I shall argue, coincided with global waves of 'New' ('Progressive' or 'Alternative') education. 


\section{Moments}

At certain historical conjunctures, 'possibility offers itself; and it reveals itself' (Lefebvre, 2002: 348). Lefebvre elaborates:

The moment has its content. It draws it from conjunctures in more-or-less external circumstances, and incorporates it. All the content of moments comes from everyday life and yet every moment emerges from the everyday life in which it gathers its materials or the material it needs. (Lefebvre, 2002: 346)

Historical 'Moments' may be experienced as personal insights or revelations, 'felt' in the course of a spiritual, emotional or artistic experience. The 'Moment', the festival, play and the arts are connected; the oeuvre (or creative work) opposing the product. Moments are characterised by playfulness, overthrowing of orthodoxies, outrageous 'works' (oeuvres) and new genres, theatrical 'occupations' of bureaucratic enclosures: all are attempts to 'replace domination by appropriation' (Lefebvre, 1996: 171).

\section{New education as Moment}

'Around 1910', Lefebvre wrote, 'a certain space was shattered' (1991c: 25). Since then, 'commonplaces' such as 'Euclidean and perspectivist space have disappeared, the tonal system in music, traditional morality. This was truly a crucial moment' (1991c: 25). He continues, 'Such were the shocks and onslaughts suffered by this space that today it retains but a feeble pedagogical reality...within a conservative education system' (Lefebvre, 1991c: 25). Expressions of the archaic, 'the mysterious, the sacred and the diabolical, magic, ritual, the mystical' (1991a: 117) - repressed in Modernity's 'social unconscious' - erupted through its fissures. New sciences, such as psychoanalysis and new psychologies, took into account the unconscious, the symbolic, the spiritual and the imaginary. Although interested in these 'new sciences', incorporated into the conceived, they became alienating 'mental spaces', transforming 'what I am into the sign of what I am' (Lefebvre, 1991c: 185).

Through the 1920s-1930s, Lefebvre associated with Paris's artistic avant-garde - Dada, Cubists and Surrealists - attracted by their attempt 'to disrupt the repetitiveness of daily routine through a kind of poetic guerrilla warfare' (Shields, 1999: 33). Lefebvre explained:

The leading surrealists sought to decode inner space and illuminate the nature of the transition from this subjective space to the material realm of the body and the outside world, and thence to social life. Consequently, surrealism has a theoretical import which was not originally recognised. (Lefebvre, 1991c: 18)

Later, influenced by Guy Debord's 'Situationists' (see Trebitsch, 2005), Lefebvre discussed this in terms of détournement: a 'mediating activity or concept' between domination and appropriation (2014: 95). He explains, 'at the moment of détournement, new aspirations appear, transposing the earlier form whenever it reveals its limitations in the face of new practices and languages' (2014: 98). A subversion from within, 'détournement was born with modern art' (Lefebvre, 2014: 95-96).

Although Lefebvre was not involved with 'New Education' per se, it was born from the same 'shattering of old certainties'. Rudolf Steiner education drew on archaic Germanic myths (Mathieson, 2015) and the Theosophical Fraternity in Education looked to ancient 
Hindu wisdom (Middleton, 2017). In these and more 'mainstream' (including Deweyan) pedagogies, new sciences, expressive arts and democratic values were blended in 'childcentred' practices oriented around student choice, artistic expression and 'learning through play' (Middleton, 2014: 57-110). But by the end of the Second World War, New Education's 'scientific' strands dominated its networks (notably the New Education Fellowship) and its spiritual or esoteric streams submerged (Middleton, 2014: 57-82; 2017). New Education's 'scientific' strands were absorbed into policies of what Lefebvre (1971) referred to as the 'bureaucratic society of controlled consumption'.

In the 1950s-1960s, western 'welfare states' enacted 'modalities of social and political practice that Marx could not possibly have foreseen' (Lefebvre, 2005: 157). Through State Modes of Production, they undertook the 'management and maintenance of capitalist growth at all spatial scales' (Brenner and Elden, 2009a: 17; see also Lefebvre, 2009a) and achieved class compromise by redistributing 'some portion, (Brenner, 2000) or even the entirety, of the social surplus' (Lefebvre, 2009a: 129). Viewing bureaucracy as the 'everyday life of the state' (2002: 42), Lefebvre urged study of 'the practical operation of its managerial spheres' (2009c; 2002: 42). Although premised on freedom and equality, 'such a State raises itself above society and penetrates into its depths, all the way into everyday life and behaviour' (Lefebvre, 2009a: 129). It produces 'public identities' (citizen, consumer) through 'the tutelary actions of institutions and administrations' (Lefebvre, 2009a: 129).

In 'tutelary' institutions, knowledge, as detailed previously, was 'marked by the ruling class' (Lefebvre, 1969: 148). Learning resulted from the dressage of policy and fragmented academic disciplines: 'cultivated human reason arises in two contradictory yet closely linked ways: as raison d'état (law, the state's organisational capacity, its ideological power), and as philosophical reason (organised discourse, logic, systematic thought)' (Lefebvre, 1968: 4).

In the 1960s, students from backgrounds unfamiliar with higher education - women, working class, migrants, indigenous, rural - flooded into institutions of higher education, where their experience was often one of alienation and marginality. The promise of equality was contradicted by the reality of inequality, a 'Moment' of critique:

Poets, artists, creative intellectuals...derive their inspiration from a marginal situation. Marginal groups alone can perceive and grasp society in its totality through the elaboration of significant representations. But the very society that asks them to be creative also attempts to subject them to its own norms and reduce their marginality. (Lefebvre, 1969: 133)

Across the western world, students rebelled - against the Vietnam War or in support of American Black Civil Rights, feminist, gay and indigenous movements. Educational subversions included 'deschooling' (Illich, 1971), 'alternative' or 'free' schools and 'student-centeredness' (Postman and Weingartner, 1971). Acknowledging his research as specific to France, Lefebvre encouraged 'specific studies of every known mode of production, every historical phase, every country' (1968: 159).

During the 1960s, Lefebvre was formulating his idea of 'autogestion' (or 'worker control'). 'Self-management' was

the opening toward the possible. It is both the way forward and the endpoint, the force that can bear the colossal load weighing on society, and which can overcome it. It shows the practical way to change life, which remains the watchword, the goal, and the meaning of a revolution. (Lefebvre, 2009d: 150) 
He saw in French student movements evidence of

self-management of learning - this is a particular but conspicuous case of self-management viewed as a pedagogy of the totality of social life. This is the only way in which it is possible to strike a decisive blow at the capitalist and bourgeois conception of knowledge as though it were a form of capital. (1969: 141)

Lefebvre predicted that a 'new period, with its problematic, its thematic and its categories (concepts) is on the horizon: the period of appropriation' (2003d: 182). He believed: 'We are already entering into that society and that period. Signs and symptoms: urban guerrilla warfare, as well as huge gatherings of "non-violent" youth, eager for contacts, encounters, love, eroticism, sexual enjoyment, joy and oblivion' (2003d: 182).

How might this be studied? While psychoanalysis had legitimated the unconscious and the erotic as objects of scientific study, Lefebvre rejected it as 'situated in a mental rather than a social space' (2014: 103); it was 'a clumsy effort' that tended 'to form a hierarchy parallel with or superimposed on others' (2003d: 182; see also Kelly, 1997). Rhythmanalysis might 'complement or supplant psychoanalysis. It situates itself at the juxtaposition of the physical, the physiological and the social, at the heart of daily life' (Lefebvre, 2005: 130). In 'neocapitalist' regimes of the 1960s, 'institutions, art, culture, and the university do not develop at the same rhythm as material production or a given technology or a particular field of knowledge' (Lefebvre, 1969: 14).

\section{'The Explosion': Paris 1968}

In French universities, Lefebvre believed, the 'dominant problems are those of urban society' (1969: 157). The bureaucratic 'buildings' of Paris's post-World-War-II campuses contrasted with the 'monuments' (or spatial works) of its ancient halls of learning. The monument:

took in all the aspects of spatiality...: the perceived, the conceived, and the lived; representations of space and representational spaces; the spaces proper to each faculty, from the sense of smell to speech; the gestural and the symbolic. Monumental space offered each member of a society an image of that membership, an image of his or her social visage. (Lefebvre, 1991c: 220)

Before the Second World War, universities were mainly bearers of 'the classical, precapitalist, pre-industrial culture that survives in liberal humanism and obsolete Encyclopedism' (Lefebvre, 1969: 119). At the heart of a vibrant Paris, the Sorbonne's cloistered 'monuments' offered scholars a 'sanctuary consecrated to private knowledge, mysterious writings and class-permeated scientificity' (1969: 119).

From the 1950s, rapid urbanisation, the baby-boom population explosion and the 'requirements of the market and the social division of labour' (1969: 119) generated the mass-produced standardised 'buildings' of modern campuses on the urban fringe. In 1965, Lefebvre took up the chair in sociology at the new University of Nanterre on the outskirts of Paris. In this suburb he observed 'misery, shantytowns, excavations for an express subway line, low-income housing projects for workers, industrial enterprises' (Lefebvre, 1969: 104). The campus was one 'conceived' by planners:

An absurd 'urbanistic' frame of mind - the ideology that goes by the name of 'urbanism' - planned these functional buildings that are utterly devoid of character...the 
'function of living' becomes specialised and reduced to a bare minimum (the habitat). (Lefebvre, 1969: 105)

Nanterre's students - unlike their more privileged counterparts at the Sorbonne - were accommodated in 'buildings, the prose of the world as opposed, or apposed, to the poetry of monuments' (Lefebvre, 1991c: 227). Adjoining their campus of grey functionalist buildings, the students saw 'misery and shantytowns'. They 'lived' the spatial contradictions Lefebvre highlights:

The contradictions in thought do not come simply from thought itself, from its ultimate incoherence or impotence, they also come from the content. Linked together they tend towards the expression of the total movement of the content and raise it to the level of consciousness. (2009b: 97)

The 'official' curriculum afforded glimpses of 'private knowledge and mysterious writings' of archaic elites (Lefebvre, 1969: 119). Yet, at the same time, through pedagogies of domination, most of its 'specialised knowledge' was 'transmitted in an authoritarian manner and managed bureaucratically. It provides a justification for the social hierarchy and is therefore interpreted and mutilated; but this does not make it any the less real' (1969: 145). The students sensed for themselves an 'absence of possibilities. The prospect of holding a "junior" position in education, industry or the bureaucratic hierarchy, worry over slow promotion, bills, transfers, apartment and cars' (1969: 107). This image of everyday existence, Lefebvre wrote, was 'far from appealing' (1969: 107).

The deadening 'habitat' of Nanterre's campus buildings reinforced these dull prospects: they were 'designed for the functions of education: vast amphitheatres, small "functional" rooms, drab halls, an administrative wing' (1969: 106). In contrast, utopian alternatives were occasionally glimpsed in the intellectual and literary heritage of the curriculum: such 'contradictions give rise to problems, and thus to a set of possibilities' inciting rebellion (Lefebvre, 2002: 209):

In such an environment the 'ordinary' begins to assume surprising 'extraordinary' qualities an everyday life permeated by culture, with manifest poverty sharply contrasting with the utopian and mythical richness of officially proposed culture and officially dispensed specialised knowledge. It is here that - more intensely than elsewhere - life partakes both of reality (its misery) and imagination (the splendour of history and the world!) This contributes substantially to the disintegration of culture, formal knowledge, and institutions. (Lefebvre, 1969: 106)

In his account of the unrest at Nanterre, Michel Trebitsch comments that it began in a small way 'with the occupation of the female hall of residence' (2005: xv). Lefebvre described this gender segregation as archaic and fuelling sexual rebelliousness:

the 'function of living' becomes specialised and reduced to a bare minimum (the habitat) - while traditional separations between boys and girls, and between work and leisure and privacy, are maintained - this community becomes the focus of sexual aspirations and rebellions. (Lefebvre, 1969: 105)

Lefebvre read the 'logic of visualisation' (1991c: 98) in modernist buildings as significations of patriarchy. Doreen Massey comments that he decoded them dialectically in terms of 
'the geometric, the optical (or visual) and the phallic' (1994: 184). In Lefebvre's words,

The arrogant verticality of skyscrapers, and especially of public and state buildings, introduces a phallic or more precisely a phallocratic element into the visual realm; the purpose of this display, of this need to impress, is to convey an impression of authority to each spectator. Verticality and height have ever been the spatial expression of potentially violent power. (Lefebvre, 1991c: 98)

In students' lived experience, this 'dialectic, far from being an inner movement of the mind, is real, it precedes the mind, in Being. It imposes itself on the mind' (Lefebvre, 2009b: 97).

As did feminists, Lefebvre described the 1950s-early 1960s as sexually repressive, especially for women: the 'dressage of girls and women was always harsh, especially in the so-called privileged classes' (2004: 42). He applauded the 'sexual revolution' sweeping across the 'western' world (his own voracious sexual liaisons won him notoriety (see Merrifield, 2006: 31-32)). Flouting of the codes of virginity, marriage and monogamy, flamboyant garments transgressing gendered dress codes: all were 'appropriations' - of bodies, of the street and the campus. Appalled at the austerity of life under socialism (as well as capitalism), Lefebvre embraced a 'new Romanticism': only a full 'cultural revolution' would 'change life'. To Lefebvre, 'Brawling, making love and dancing had more of the appeal of life lived in its fullness compared with dusty academic philosophers' (Shields, 1999: 14).

Spontaneous eruptions of the lived - the erotic, the imaginary, the poetic - through the grey bureaucratic rigidities of conceived spaces were, in Lefebvre's sense, illustrative of the Moments 'that break through the dull monotony of the taken-for-granted' (Shields, 1999: 56). Lefebvre wrote that 'Everyday mundanity, its time and space, contained things that were seemingly incompatible with it - play, the Festival, surprise - and hence the possibility of presenting this profundity and putting it into perspective' (Lefebvre, 1991a: 15).

The students appropriated lecture rooms, offices and corridors. They jammed city streets with noisy demonstrations. They emblazoned buildings with slogans and murals. Rejecting the dressage of the (overt and covert) curriculum, they organised teach-ins. Through these pedagogies of appropriation, the 'movement began to raise questions of ideology and "values". The question of specialised knowledge came to the fore. This type of knowledge - fragmented, departmentalised - is condemned by the most perceptive students' (Lefebvre, 1969: 111).

The 'explosion' of 1968 vented discontent that had been simmering in Europe from the 1950 s. In the 1960s, Lefebvre argued, an 'original dialectic movement begins to emerge social marginality against centralisation, anomie against norms, contestation against decisions' (2005: 24). He continued, 'Was not this wave of contestation the provisional form of a comprehensive movement directed against fixed hierarchies, established apparatuses, enforced silence, and the ideologies of domination?' The protesters had 'rejected the productivist ideology that passed for "pure" knowledge, as well as the reorganisation of daily life around the couplet "production-consumption" (Lefebvre, 2005: 24). Their mantra was 'change life'. However, the movement lacked coherence: revolutionary Marxists and subversives 'were dissociated. Failure ensued. The critique of everyday life did not attain its goal' (Lefebvre, 2005: 29).

Although Lefebvre was not directly involved with the Romanticism of the early 20th century 'New Education' or the 'deschooling' impulse of the late 1960s, his writing suggests historical and philosophical affinities, offering a new line of inquiry for educational research. 


\section{The late 20th century}

In 1981 Lefebvre introduced the third volume of Critique: 'Modernity is dated: industrial society, with the abstraction paradoxically produced by material production' (2005: 92). Capitalist expansion had extended 'the market and commodities to the entire earth' (p.53). Everyday life was increasingly rhythmed by 'the production and exchange of nonmaterial goods' (p.92), with information the 'supreme' and 'ultimate commodity'. State bureaucracies 'administered society like an enterprise within an enormous, technocratically administered system...every moment anticipated, quantified in money terms, or programmed temporally and spatially' (p.57).

Infusing the administrative practices (pedagogies) of commercial and state bureaucracies, a technocratic neo-liberal raison d'état was producing a new 'human nature': the "substitution of the "user", figure of daily life, for the political figure of the "citizen"" (Lefebvre, 2005: 78). In universities the intellectual priority of creativity - the original 'work' (oeuvre) - was supplanted by demands for proliferation of 'products', ('outputs' in today's jargon). Lefebvre observed: 'what a lot of researchers there are! And research! People search and search without finding anything very much. Rather than oeuvres, we have essays, attempts, cross-references, overtures' (2005: 162). As detailed elsewhere (Middleton, 2014: 142-171), in today's universities, dominated by audits and rankings, Lefebvre's predictions seem prescient.

At a time before public availability of personal computers or the Internet, Lefebvre envisaged an imminent 'computerised daily life' of technological alienation (2005: 151). The worker/scholar would be reduced to an

individual atom... inside a bubble where the messages sent and received intersect. Users, who have lost the dignity of citizens now that they figure socially only as parties to services, would thus lose the social itself, and sociability. This would no longer be the existential isolation of the old individualism, but a solitude all the more profound for being overwhelmed by messages.

Are we condemned to insulated drudgery under disciplinary surveillance by grey bureaucracies? No, says Lefebvre: 'the politico-bureaucratic-state edifice always contains cracks, chinks, spaces. On the one hand, administrative activity strains to plug these gaps... On the other hand, individuals seek to enlarge these cracks and pass through the interstices' (2005: 127).

\section{Conclusion}

This 'educational reading' of those of Lefebvre's works available in English has identified numerous references to schools, universities and to pedagogy more broadly. Yet these have been largely overlooked by Lefebvre's translators, editors and commentators, who have not seen them as significant enough to include in an index. While Lefebvre saw architecturally and linguistically configured spaces of schools and universities as crucial in the 'production of human nature', he also viewed pedagogy more broadly. As with today's concept of a 'public pedagogy', it need not involve teaching, as 'learning takes place across a spectrum of social practices and settings' (Giroux, 2004: 60). Encompassing all experiences, processes or practices that effect learning, Lefebvre's idea of the pedagogical was based on Marx's tenet 
that the 'human being is historical and its historicity is inherent to it: it produces and is produced, it creates a world and creates itself' (Lefebvre, 2002: 20).

In 1948, in launching his lifelong project of critique of everyday life, Lefebvre outlined a pedagogical vision:

The individual will stop being a fiction, a myth of the bourgeois democracies ... Our pedagogy, our psychology, are but tentative sketches for these future techniques, which will make the subject into an object for itself (and therefore more real) and the social and biological object into a subject (consciousness, freedom, active power). (1991a: 248)

His writings indicate directions such 'future techniques' might take.

A 'pedagogy of appropriation' required 'the appropriation of the body, as of spatial practice' (Lefebvre, 1991c: 205). The architectural and linguistic configurations of schools and universities alienated the 'rational mind' from embodied everyday spatial practices (the perceived). In appropriated spaces of leisure, such as beaches, Lefebvre suggested that 'a pedagogy of space and time is beginning to take shape' (1991c: 384, emphasis in the original) as holidaymakers experienced 'contradictions between abstract space and the possibility of its "other"' (Stanek, 2014: xxxi). 'How', Lefebvre asks, 'can we re-educate bodies for space?' (2014: 34). 'We need', he suggests, 'a kind of pedagogy of the body, its rhythms, a kind of teaching' to 'fill the enormous gap. But such unpleasant words: pedagogy, teaching, fill!' (p.34). A pedagogy of the body 'is a practice, addressed to lived experience, to lead it to the level of the perceived world' (p.34). It is a 'poetic practice, that attempts to vivify the entire body with all its rhythms and senses' (p.35): it attends to movement and gesture, smell, touch, taste and sound (Lefebvre, 1991c: 191, 197-200; 2014: 36-42). Accordingly, sports, theatre, dance, cookery, sculpture, music, painting and 'play' (Lefebvre, 1996: 171) are important.

An educator 'is not a mere conveyor, nor is the institution called a university a warehouse' (Lefebvre, 1969: 159). A pedagogy of appropriation requires 'self-management of learning' (1969: 141). Teachers and students engage in collective critique of everyday life. Critique is a pedagogy: 'To study the everyday is to wish to change it.' Acknowledging that daily life changes 'by two routes, the local and the global, the micro and the macro' (Lefebvre, 2005: 126), a Lefebvrian critical pedagogy orients itself from the inside of 'the reality we are studying. We are setting out from its inner movement and from what is possible' (Lefebvre, 2002: 56). It undertakes 'the disenchantment of the state and the sphere of power' (2005: 126) by engaging with (historical and contemporary) 'contradictions' and 'moments' that render(ed) critique possible. In universities and schools, such 'pedagogic originality requires genius' (1969: 159).

\section{Declaration of Conflicting Interests}

The author declared no potential conflicts of interest with respect to the research, authorship, and/or publication of this article.

\section{Funding}

The author received no financial support for the research, authorship, and/or publication of this article. 


\section{References}

Bachelard G (2002) The Poetics of Space. Boston, MA: Beacon Press.

Brenner N (2000) The urban question as a scale question: Reflections on Henri Lefebvre, urban theory and the politics of scale. International Journal of Urban and Regional Research 24(2): 361-378.

Brenner N and Elden S (2009a) Introduction. State, space, world: Lefebvre and the survival of capitalism. In: Brenner N and Elden S (eds) Henri Lefebvre, State, Space, World: Selected Essays. Minneapolis, MN: University of Minnesota Press, pp.1-48.

Brenner N and Elden S (eds) (2009b) Henri Lefebvre, State, Space, World: Selected Essays. Minneapolis, MN: University of Minnesota Press.

Elden S (2004) Understanding Henri Lefebvre: Theory and the Possible. London and New York: Continuum.

Elden S (2006) Between Marx and Heidegger: Politics, philosophy and Lefebvre's Production of Space. Antipode 36(1): 86-105.

Elden S, Lebas E and Kofman E (eds) (2003) Henri Lefebvre: Key Writings. London and New York: Continuum.

Ford DR (2013) Toward a theory of the educational encounter: Gert Biesta's educational theory and the right to the city. Critical Studies in Education 54(3): 299-310.

Foucault M (1977) Discipline and Punish. Harmondsworth: Penguin.

Giroux H (2004) Cultural studies, public pedagogy and the responsibilities of intellectuals. Communication and Critical/Cultural Studies 1(1): 59-79.

Gulson KL and Symes C (eds) (2007) Spatial Theories of Education: Policy and Geography Matters. New York and London: Routledge.

Harvey D (1991) Afterword. In: Lefebvre H (ed) The Production of Space. Oxford: Blackwell, pp.425434.

Illich I (1971) Deschooling Society. Harmondsworth: Penguin.

Kelly M (1997) The historical emergence of everyday life. Sites: The Journal of Contemporary French Studies 1(1): 77-91.

Kipfer S (2009) Preface to the New Edition. Dialectical Materialism. Minneapolis, MN: University of Minnesota Press, pp.xiii-xxxii.

Kofman E and Lebas E (1996b) Introduction: Lost in transposition - time, space and the city. In: Kofman E and Lebas E (eds) Henri Lefebvre, Writings on Cities. Oxford, UK, and Cambridge, MA: Blackwell, pp.3-62.

Lefebvre H (1968) The Sociology of Marx. Allen Lane.

Lefebvre H (1969) The Explosion: Marxism and the French Upheaval. London and New York: Monthly Review Press Classics.

Lefebvre H (1971) Everyday Life in the Modern World. London: Penguin.

Lefebvre H (1991a) Critique of Everyday Life Vol 1. London and New York: Verso.

Lefebvre H (1991b) Foreword to the second edition, Paris, December 1956 to February 1957. In: Lefebvre H (ed.) Critique of Everyday Life Vol 1. London and New York: Verso, pp.1-99.

Lefebvre H (1991c) The Production of Space. Oxford: Blackwell.

Lefebvre H (1996) Right to the city. In: Kofman E and Lebas E (eds) Henri Lefebvre: Writings on Cities. Oxford, UK, and Cambridge, MA: Blackwell, pp.63-181.

Lefebvre H (2002) Critique of Everyday Life Vol 2: Foundations for a Sociology of the Everyday. London and New York: Verso.

Lefebvre H (2003a) Levels and dimensions (1970). In: Elden S, Lebas E and Kofman E (eds) Henri Lefebvre: Key Writings. New York and London: Continuum, pp.136-150.

Lefebvre H (2003b) Preface to the new edition of Production of Space. In: Elden S, Lebas E and Kofman E (eds) Henri Lefebvre: Key Writings. New York and London: Continuum, pp.206-215. 
Lefebvre H (2003c) Preface to the study of the Habitat of the 'Pavillon' (1966). In: Elden S, Lebas E and Kofman E (eds) Henri Lefebvre: Key Writings. New York and London: Continuum, pp.121-135.

Lefebvre H (2003d) Time and history. In: Elden S, Lebas E and Kofman E (eds) Henri Lefebvre: Key Writings. New York and London: Continuum, pp.177-187.

Lefebvre H (2004) Rhythmanalysis: Space, Time and Everyday Life. London and New York: Athlone.

Lefebvre H (2005) Critique of Everyday Life Vol 3: From Modernity to Modernism. London and New York: Verso.

Lefebvre H (2009a) Comments on the new state form (1979). In: Brenner N and Elden S (eds) Henri Lefebvre, State, Space, World: Selected Essays. Minneapolis, MN: University of Minnesota Press, pp.124-137.

Lefebvre H (2009b) Dialectical Materialism. Minneapolis, MN: University of Minnesota Press.

Lefebvre H (2009c) The worldwide experience (1978). In: Brenner N and Elden S (eds) Henri Lefebvre, State, Space, World: Selected Essays. Minneapolis, MN: University of Minnesota Press, pp.274-289.

Lefebvre H (2009d) Theoretical problems of autogestion (1966). In: Brenner N and Elden S (eds) Henri Lefebvre, State, Space, World: Selected Essays. Minneapolis, MN: University of Minnesota Press, pp.138-152.

Lefebvre H (2014) Toward an Architecture of Enjoyment. Minneapolis, MN: University of Minnesota Press. Massey D (1994) Space, Place and Gender. Cambridge: Polity.

Mathieson A (2015) Rhythms in education and the art of life - Lefebvre, Whitehead and Steiner on the art of bringing rhythmical transformations into teaching and learning. Research on Steiner Education 6(2): 36-51.

Merrifield A (2006) Henri Lefebvre: A Critical Introduction. New York and Abington: Routledge.

Middleton S (2010) Labourers' letters from Wellington to Surrey, 1840-1845: Lefebvre, Bernstein and pedagogies of appropriation. History of Education 39(4): 459-479.

Middleton S (2012) Putting Sylvia in her place: History, geographical theory and the new education. Paedagogica Historica 48(2): 263-282.

Middleton S (2014) Henri Lefebvre and Education: Space, History, Theory. Abington and New York: Routledge.

Middleton S (2017) [Forthcoming] New Zealand theosophists in global 'New Education' networks, 1916-48. History of Education Review 46(2).

Middleton S and McKinley E (2010) The gown and the korowai: Māori doctoral students and the spatial organisation of academic knowledge. Higher Education Research and Development 29(3): $229-243$.

Moran J (2010) History, memory and the everyday. Rethinking History: The Journal of Theory and Practice 8(1): 51-68.

Postman N and Weingartner C (1971) Teaching as a Subversive Activity. Harmondsworth: Penguin.

Shields R (1999) Lefebvre, Love and Struggle: Spatial Dialectics. London and New York: Routledge.

Simonsen K (2005) Bodies, sensations, space and time: The contribution from Henri Lefebvre. Geografiska Annaler 87(1): 1-14.

Stanek L (2014) Introduction: A manuscript found in Saragossa. In: Lefebvre H (ed.) Toward an Architecture of Enjoyment. Minneapolis, MN: University of Minnesota Press, pp.xi-lxi.

Trebitsch M (2005) Preface: Presentation - twenty years after. In: Lefebvre H (ed.) Critique of Everyday Life Vol 3: From Modernity to Modernism. London and New York: Verso, pp.vii-xxxiv.

\section{Sue Middleton}

